\title{
MENJAGA KELESTARIAN HUTAN DAN SIKAP CINTA LINGKUNGAN BAGI PESERTA DIDIK MI/SD
}

\author{
Nazwa Ahada \\ Anis Fuadah Zuhri \\ UIN Syarif Hidayatullah Jakarta \\ Jl. Ir. H. Djuanda No. 95, Cempaka Putih, Ciputat Timur, Tangerang Selatan \\ 15412, Banten, Indonesia \\ nazwaahada16@gmail.com
}

Naskah masuk: 22-10-20, direvisi: 21-01-20, diterima: 11-02-20, dipublikasi: 30-04-20

\begin{abstract}
Abstrak: Kelestarian hutan merupakan hasil berbagai proses yang terjadi dalam kehidupan dari ekologi hutan. Sebuah ekosistem hutan memiliki sistem sosial yang terdiri dari manusia dengan proses-proses sosial dan kemudian terdapat lingkungan ekosistem itu sendiri. Permasalahan yang terjadi seperti pembakaran dan penebangan hutan merupakan salah satu faktor yang mampu memberikan dampak signifikan bagi keberadaan lingkungan dan kehidupan di dalamnya. Dalam artikel ini akan mengkaji tentang kelestarian hutan dan menumbuhkan rasa cinta lingkungan bagi peserta didik MI/SD di Indonesia dengan cara membahas berbagai materi yang terkait dengan 1) kondisi kelestarian hutan di Indonesia. 2) menjaga dan menumbuhkan rasa cinta lingkungan. Metode yang digunakan yaitu melalui media pembelajaran interaktif yang memanfaatkan teknologi komputer sebagai perangkat untuk menggunakannya. Artikel ini bertujuan untuk meningkatkan nilai-nilai melestarikan hutan dan cinta lingkungan khususnya pada tingkat pendidikan sekolah dasar.

Kata kunci: Kelestarian Hutan, Kondisi Hutan Indonesia, Cinta Lingkungan
\end{abstract}

\begin{abstract}
Forest sustainability is the result of various processes that occur in the life of the forest ecology. A forest ecosystem has a social system consisting of humans with social processes and then there is the environment of the ecosystem itself. Problems that occur such as burning and logging are one of the factors that can provide a significant impact on the existence of the environment and life in it. In this article, we will study the sustainability of forests and foster environmental love for MI / SD students in Indonesia by discussing various materials related to 1) the condition of forest sustainability in Indonesia. 2) maintain and foster a sense of love for the environment. The method used is through interactive learning media that utilizes computer technology as a device to use it. This article aims to increase the values of preserving the forest and love the environment, especially at the level of primary school education.
\end{abstract}

Keywords: Forest Sustainability, Indonesian Forest Conditions, Love the Environment

\section{PENDAHULUAN}

Indonesia merupakan salah satu negara yang memiliki kekayaan alam dan keanekaragaman hayati yang sangat penting bagi kehidupan, salah satunya adalah hutan. Hutan Indonesia memiliki peranan penting dalam menjaga kestabilan iklim dunia. Selain itu, hutan merupakan sumber daya alam yang tidak ternilai karena didalamnya terkandung keanekaragaman hayati sebagai sumber hasil hutan kayu dan non kayu dan memiliki fungsi lain, yakni sebagai pengatur tata air, penanggulangan bencana, serta sebagai pelindung flora dan fauna dan merupakan paru-paru dunia yang dapat menyerap karbondioksida dan menyediakan oksigen bagi kehidupan dimuka bumi ini. Hutan sebagai suatu ekosistem tidak hanya menyimpan sumber daya alam yang berupa kayu atau buah tetapi masih banyak potensi lain yang dapat diambil manfaatnya oleh 
manusia baik secara langsung maupun tidak langsung. Hutan merupakan kunci dalam menjaga ekosistem dunia, jika hutan kita dirusak dengan skala stadium berat, maka implikasinya terjadi pemanasan global (global warming) yang menimbulkan instabilitas iklim dunia. Hutan lindung yang sebagai ekosistem sangat dibutuhkan untuk mencegah terjadinya banjir. Tidakkah kita sadari bahwa hutan lindung sangat penting guna menjaga tata air dan kesuburan tanah? Wajah lahan semakin gundul, maka tak heran jika setiap musim hujan tiba, luapan air sungai yang besar seketika menjelma jadi banjir, karena hilangnya fungsi hutan lindung.

Semua manusia pasti menginginkan lingkungan yang indah dan lestari, namun pada kenyataannya manusia itu sendiri yang membuat lingkungan tidak indah dan lestari lagi. Salah satunya aktivitas manusia yang dapat merusak hutan, manusia kebanyakan cenderung merusaknya di bandingkan untuk merawat hutan itu sendiri. Pada dasarnya manusia dan hutan memiliki hubungan yang erat, dimana keduanya saling menerima dan memberi pengaruh yang besar satu sama lain. Hutan cenderung akan memberikan timbal balik kepada manusia, jika manusia bersikap positif terhadap hutan maka hutanpun akan membalasnya dengan yang positif terhadap manusia itu sendiri. Contohnya yaitu udara bersih, iklim yang teratur, dapat menampung stok air pada musim hujan dan kemarau, mencegah longsor, dll. Namun, jika manusia bersikap negatif terhadap hutan baik langsung maupun tidak langsung hutan atau alam itu sendiri akan membalasnya dengan hal-hal yang negative pula. Manusia dapat mempengaruhi hutan dan begitu juga sebaliknya hutanpun dapat mempengaruhi manusia, jika hutan rusak maka kehidupan habitat di dalamnya pun akan rusak yang kemudian akan punah.
Hutan yang merupakan sebuah kawasan yang ditumbuhi oleh pepohonan dan tumbuhan lebat terdapat dalam kawasankawasan di wilayah yang luas di dunia dan berfungsi sebagai penampung karbon dioksida, habitat hewan, dan pelestari tanah. Konsep kelestarian hutan banyak disebut konsep kelestarian yang dibutuhkan saat ini, karena mengingat kondisi hutan yang mengkhawatirkan diperlukan strategistrategi dalam menjaga akan kelestarian hutan dan tentunya diperlukan peran semua masyarakat dalam menopang dan mewujudkan terciptanya lingkungan yang senantiasa terjaga keasriannya. Etika lingkungan menjadi suatu peran dari beberapa aspek kelestarian hutan karena dengan etika lingkungan bisa membatasi tingkah laku dan upaya untuk mengendalikan kegiatan agar tetap berada dalam batas kepentingan lingkungan. Dimana dalam merealisasikan itu semua, mampu berkomitmen dan konsisten dengan segala upaya yang berhubungan dengan pelestarian hutan dan lingkungan. Mengajarkan sedini mungkin kepada anakanak akan pentingnya hutan dan menumbuhkan sikap peduli akan lingkungan termasuk dalam salah satu bentuk kelestarian hutan yang bersifat langsung dalam kehidupan sehari-hari dengan menanam pohon disekitar rumah/sekolah, merawat taman, menebang pohon dengan sistem tebang-pilih, dan lainnya. Dari hal-hal kecil itu cenderung akan tertanam dalam diri mereka kecintaan kepada hutan dan ekosistemnya. Hal ini sebagai salah satu proses untuk menyiapkan generasi penerus bangsa yang menanamkan karakter akan cinta lingkungan. Selain itu pendidikan lingkungan juga berperan dalam pelestarian hutan dimana membentuk generasi penerus bangsa sadar akan lingkungan yaitu diharapkan mampu membentuk karakter manusia yang mencintai lingkungannya, 
sekolah merupakan tempat anak-anak untuk belajar pengetahuan secara formal dan mengajarkan untuk berpikir ilmiah. Sekolah dasar adalah tempat yang paling tepat untuk memberikan pemahaman terhadap siswa akan lingkungan hidup karena sekolah dasar merupakan awal dari manusia belajar pengetahuan secara normal, penanaman pondasi pendidikan akan cinta lingkungan semakin baik bila dilakukan sejak dini.

Berdasarkan latar belakang tersebut, maka penulis tertarik untuk mengkaji persoalan tentang bagaimana meningkatkan kesadaran untuk melestarikan hutan dan lingkungan dengan tujuan agar terciptanya lingkungan yang indah dan lestari, serta mempertahankan kekayaan sumber daya alam yang sangat bermanfaat bagi kehidupan masyarakat Indonesia.

\section{METODE}

Metode yang digunakan dalam kajian ini menggunakan metode studi pustaka, pendekatan kepustakaan atau studi pustaka diartikan sebagai serangkaian kegiatan yang berkenaan dengan metode pengumpulan data pustaka, membaca, dan mencatat serta mengolah bahan penelitian. Dalam penelitian studi pustaka memiliki ciri bahwa penulis atau peneliti berhadapan langsung dengan dengan teks atau data angka, bukan dengan pengetahuan langsung dari lapangan. Data pustaka bersifat siap pakai yang artinya peneliti tidak terjun langsung ke lapangan karena berhadapan langsung dengan sumber data yang ada di perpustakaan. Data pustaka umumnya adalah sumber sekunder, bahwa peneliti memperoleh bahan atau data pustaka tidak dibatasi oleh ruang dan waktu. (Supriyadi, 2017). Dalam proses menulis artikel ini, penulis mengumpulkan seluruh data yang berkaitan dengan tema bahasan yaitu mengenai sikap dan perilaku seseorang untuk menjaga kelestarian hutan dan menanamkan sikap cinta lingkungan bagi siswa MI/SD. Kemudian, setelah memiliki sumber yang cukup, peneliti membaca secara mendalam, menganalisis data dari semua sumber yang dapat dipercaya dan meringkasnya menjadi sebuah kesimpulan yang padat.

\section{HASIL DAN PEMBAHASAN}

Artikel ini bertujuan untuk menjelaskan pentingnya menjaga kelestarian hutan dan lingkungan khususnya pada anak usia dini, Indonesia yang akan luas dengan hutan dan sumber daya alam bahkan hutan Indonesia menjadi paru-paru dunia. Namun, kondisi hutan mengalami penurunan seiring berjalannya waktu sehingga tutupan lahan hutan berkurang diakibatkan oleh kurangnya kesadaran manusia dengan lingkungannya. Dari hasil penelitian dapat diketahui bahwasannya sikap peduli lingkungan harus ditingkatkan, etika lingkungan perlu diterapkan di masyarakat dan pendidikan lingkungan hidup terutama pada anak-anak sekolah dasar sebagai generasi yang akan mendatang guna mengurangi kerusakan dan bahkan dapat meningkatkan kualitas keseimbangan alam.

Berikut ini merupakan pembahasan terkait hasil penelitian, diantaranya adalah sebagai berikut.

\section{Kelestarian Hutan di Indonesia}

Sebagian besar wilayah Indonesia adalah kawasan hutan. Hutan menyimpan banyak sekali keberagaman jenis flora dan fauna serta merupakan salah satu kekayaan sumber daya alam yang secara umum mempunyai peranan cukup penting bagi kehidupan yang ada dibumi. Hutan adalah suatu kesatuan ekosistem berupa hamparan lahan berisi sumber daya alam hayati yang didominasi pepohonan dalam persekutuan alam lingkungannya dan satu dengan lainnya tidak dapat dipisahkan. Hutan yang 
sebagai sumber daya alam dapat memberikan manfaat berlipat ganda, baik manfaat yang langsung sebagai sumber berbagai jenis barang seperti kayu, getah, kulit kayu, daun, akar, buah, bunga yang dapat dimanfaatkan secara langsung oleh manusia dan maupun manfaat yang tidak langsung berupa perlindungan lingkungan, pengelolaan tata air, memberikan keindahan, kenyamanan, dan lain-lain. Selain itu hutan juga bisa menjadi bahan baku sebagai industri dan hasilnya dapat digunakan untuk memenuhi hampir semua kebutuhan manusia.

Di samping itu, hutan mempunyai sifat khusus yang sangat khas yaitu dapat dikelola secara lestari dan dapat diperbaharui atau dipulihkan kembali. Salah satu elemen penting dalam pengelolaan hutan adalah konsep pelestarian, khususnya menyangkut kelestarian hasil hutan. Pelestarian dalam pengertian yang luas merupakan salah satu penerapan yang penting dari sistem ekologi. Tujuan dari pelestarian yang sebenarnya adalah memastikan pengawetan kualitas lingkungan yang mengindahkan estetika dan kebutuhan maupun hasilnya serta memastikan kelanjutan hasil tanaman, hewan, bahan-bahan yang berguna dengan menciptakan siklus seimbang antara panenan dan pembaharuan ( $F, 2011)$. Pelestarian hutan merupakan upaya melindungi hutan dari kerusakan hutan, kawasan hutan, dan hasil hutan yang disebabkan perbuatan manusia, ternak, kebakaran, daya-daya alam, hama, serta penyakit. Pelestarian hutan dimaksudkan untuk mempertahankan dan menjaga hakhak negara, masyarakat, dan perorangan atas hutan, kawasan hutan, hasil hutan, investasi serta perangkat yang berhubungan dengan pengelolaan hutan.

Indonesia adalah Negara kepulauan terbesar di dunia, yang mengalokasikan 63\% atau seluas 120,6 juta hektar daratannya, sebagai kawasan hutan yang merupakan wilayah tertentu dan ditetapkan oleh pemerintah untuk dipertahankan keberadaanya sebagai hutan tetap. Sebagaimana amanat Undang-Undang Dasar 1945, prasyarat menuju pengelolaan hutan secara lestari dan berkelanjutan, tidak terlepas dari kebutuhan data dan informasi yang lengkap, terpercaya dan terkini (KLHK, 2018). Salah satu informasi yang dibutuhkan adalah bagaimana kondisi tutupan hutan dan penggunaan lahan, karena informasi ini menjadi landasan ketika hendak merencanakan, memanfaatkan serta untuk melakukan evaluasi terhadap pengelolaan sumber daya hutan yang mampu menjamin kelestarian hutan dan meningkatkan kemakmuran rakyat. Kementerian Kehutanan sebagai lembaga penyedia data resmi kehutanan mengatakan bahwa kelemahan tata kelola telah menyebabkan tutupan hutan Indonesia terus berkurang. Di Indonesia sendiri keberadaan hutan sangat berlimpah jumlahnya, ada berbagai macam hutan yang ada di indonesia diantaranya adalah hutan mangrove yang wilayah persebaran nya yaitu hampir menyeluruh didaerah pesisir pantai dan hutan rawa dengan persebarannya di daerah sumatera, kalimantan dan papua, lalu hutan hujan tropis dengan persebaran di daerah kalimantan, papua, maluku dan sebagian pulau jawa.

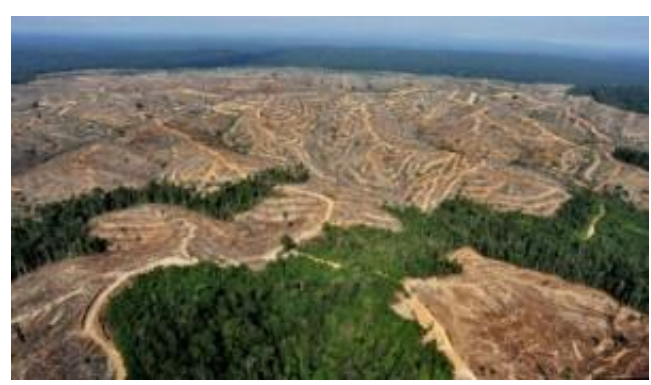

Gambar 1. Kondisi Deforestasi pada Hutan Indonesia

Sumber: (Deforestasi Potret Buruk Tata Kelola Hutan, per 17 Maret 2020) 
Deforestasi dan degradasi hutan menjadi perhatian utama bagi Negara berkembang, termasuk Indonesia. Deforestasi dan degradasi hutan bisa saja terjadi karena adanya kegiatan yang diperlukan untuk pembangunan sektor kehutanan maupun non kehutanan. Indonesia telah merasakan dampak positif dan dampak negatif dari deforestasi. Pada masa sulit setelah kemerdekaan, deforestasi dianggap berdampak positif karena memberikan pendapatan pada negara. Sejak Tahun 1966 sampai akhir Tahun 1980an, Indonesia merupakan eksportir kayu bulat serta sebagai produsen kayu lapis terbesar di dunia. Setelah jatuhnya harga minyak bumi pada Tahun 1982, kayu bulat merupakan penyumbang devisa terbesar kedua bagi Indonesia.

Pada Tahun 1980-an, para peneliti mulai memperhatikan berkurangnya luas hutan di negara berkembang, termasuk Indonesia. Sejak saat itu, dimulailah pemahaman, bahwa deforestasi menimbulkan implikasi negatif bagi sumber daya hutan. Kegiatan yang diindikasikan menjadi penyebab deforestasi di Indonesia antara lain seperti pembangunan infrastruktur, permintaan untuk ekspor kayu bulat, pertumbuhan dan kepadatan penduduk, urbanisasi dan perluasan daerah perkotaan, harga-harga komoditas (kayu bulat, kelapa sawit, batu bara, bauksit, dan nikel), aksesibilitas geografis indnesia terhadap pasar, kemiskinan, keamanan penguasaan lahan dan konflik, serrta upah pekerjaan pasca panen (KLHK, 2018).

Dalam perspektif ilmu kehutanan deforestasi dimaknai sebagai situasi hilangnya tutupan hutan beserta atributatributnya yang berimplikasi pada hilangnya struktur dan fungsi hutan itu sendiri. Pemaknaan tersebut diperkuat oleh definisi deforestasi yang dituangkan dalam
Peraturan Menteri Kehutanan Republik Indonesia No. P.30/Menhut- II/2009 tentang Tata Cara Pengurangan Emisi dari Deforestasi Dan Degradasi Hutan yang dengan tegas menyebutkan bahwa deforestasi adalah perubahan secara permanen dari areal berhutan menjadi tidak berhutan yang diakibatkan oleh kegiatan manusia. pada setiap tipe hutan melekat seluruh atribut baik struktural maupun fungsional, sehingga terbentuk pula karakteristik masing-masing tipe hutan tersebut. Atribut struktural adalah komposisi jenis, keanekaragaman, distribusi spasial, stratifikasi tajuk dan lain sebagainya. Sedangkan atribut fungsional adalah produktivitas hutan, jasa lingkungan, siklus hara, pengontrol erosi dan lain sebagainya. Dalam keadaan seimbang, struktur akan menentukan fungsi, demikian juga sebaliknya. Dengan ini ditegaskan bahwa situasi dimana setiap aktivitas yang berakibat pada hilangnya hutan beserta atribut dan fungsinya baik di dalam kawasan hutan maupun di luar kawasan hutan disebut deforestasi. (Barri et al., 2018)

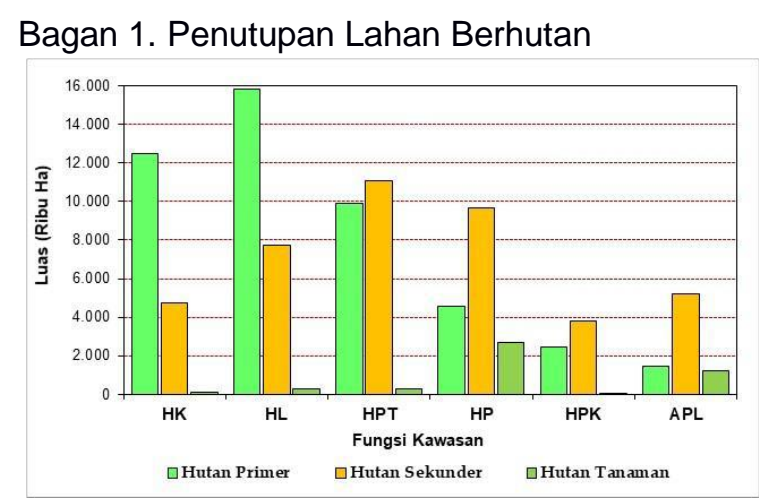

Berdasarkan tabel dan gambar diatas, dapat dilihat bahwa dari penutupan lahan berhutan seluas 93,5 juta ha, 46,7 juta ha atau $49,9 \%$ merupakan hutan primer, 42,6 juta ha atau $45,2 \%$ merupakan hutan sekunder dan selebihnya merupakan hutan tanaman, yaitu seluas 4,6 juta ha $(4,9 \%)$. 
Kondisi hutan primer terluas terdapat di hutan lindung, sedangkan hutan sekunder umumnya terdapat pada hutan produksi, dan sebagian pada hutan lindung. Hutan tanaman sebagian besar terdapat pada hutan produksi. Kondisi hutan pada areal penggunaan lain sebagian besar merupakan hutan sekunder. $(2019,2012)$.

\section{Bagan 2. Penutupan Fungsi Kawasan Hutan}

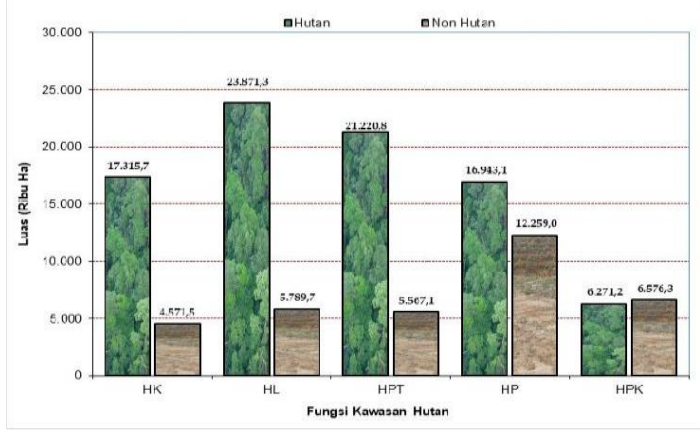

Berdasarkan fungsi kawasan hutan, penutupan lahan berhutan pada kawasan hutan konservasi sebesar 17,3 juta ha $(79,1 \%)$ dan tidak berhutan sebesar 4,6 juta ha $(20,9 \%)$, kawasan hutan lindung sebesar 23,9 juta ha $(80,5 \%)$ dan tidak berhutan sebesar 5,8 juta ha $(19,5 \%)$, kawasan hutan produksi sebesar 44,4 juta ha $(64,6 \%)$ dan tidak berhutan sebesar 24,4 juta ha $(35,4 \%)$. Sedangkan lahan berhutan pada areal penggunaan lain seluas 7,9 juta ha $(11,7 \%)$ dan tidak berhutan seluas 59,5 juta ha (88,3\%). (2019, 2012). Data luas tutupan hutan ini harus dilihat dalam konteks Indonesia sebagai negara kepulauan, di mana masing-masing gugus pulau besar memiliki karakter alam yang berbeda sedangkan pulau-pulau kecil memiliki kerentanan lingkungan yang khas pula dan membutuhkan daya dukung hutan secara tertentu. Demikianlah sehingga dalam konteks pengelolaan hutan, faktor kondisi geografis dan kerentanan wilayah akibat adanya aktivitas konversi hutan di suatu pulau, khususnya di pulau-pulau kecil, seharusnya menjadi pertimbangan penting dalam menentukan arah kebijakan pengelolaan hutan. Karena sekecil apapun konversi yang terjadi, secara langsung akan berdampak terhadap keselamatan lingkungan dan kehidupan masyarakat yang tinggal di pulau tersebut (Barri et al., 2018).

\section{Strategi menjaga kelestarian hutan di Indonesia}

Tutupan lahan pada kawasan hutan sangat dinamis dan berubah, dimana kondisi hutan semakin menurun dan luas tutupannya berkurang. Beberapa kegiatan yang menjadi penyebab pengurangan luas hutan yaitu konversi kawasan hutan untuk tujuan pembangunan sektor lain, pengelolaan hutan yang tidak lestari, pencurian kayu, penebangan liar, pertambangan, dan okupasi lahan serta kebakaran hutan. Di sisi lain, belum optimalnya kegiatan penghijauan dan reboisasi yang mengakibatkan semakin luasnya lahan kritis, untuk mengatasi kondisi tersebut diperlukan perubahan tata kelola hutan ke arah yang lebih baik termasuk dalam hal pemantauan sumber daya hutan.

Kerusakan lingkungan pun dapat dirasakan meningkat seiring dengan meningkatnya deforestasi. Selama ini pembangunan yang dilakukan dalam rangka meningkatkan pertumbuhan ekonomi, sedangkan aspek-aspek sosial budaya dan lingkungan hidup kurang diperhatikan bahkan ditinggalkan. Dalam pandangan ekologi sebagai ilmu yang mempelajari hubungan antara makhluk hidup dengan lingkungannya, bahwa manusia akan tetap bertahan hidup hanya jika terdapat keseimbangan antara keutuhan ekosistem dan kebutuhan manusia terhadap sumber daya lingkungannya. Adanya kearifan ekologis yang diterapkan oleh masyarakat dalam mengelola sumber daya hutan, karena kearifan ekologis merupakan nilainilai yang sangat erat hubungannya dengan 
ajaran agama dan kepercayaan yang dimiliki. Sumber daya hutan perlu dikelola dan dimanfaatkan secara optimum sebagai satu kesatuan ekosistem yang terintegrasi dalam kepentingan ekonomi, sosial dan lingkungan berdasarkan prinsip pengelolaan hutan lestari, yang menjamin keberlanjutan fungsi-fungsi produksi, ekologi dan sosial dari sumber daya hutan tersebut. Hutan merupakan komponen utama dari suatu ekosistem, karenanya pengelolaan hutan secara langsung akan mempengaruhi komponen lainnya seperti tanah, air, udara, iklim mikro dan lingkungan secara keseluruhan (Adinugraha, 2008).

Selama ini program-program pengelolaan hutan dalam bentuk Community Based Forest Management yang telah diimplementasikan di beberapa Asia Tenggara dan sudah diadopsi lalu diimplementasikan di Indonesia dalam bentuk Pengelolaan Hutan Bersama Masyarakat (PHBM). Pengelolaan seperti ini direkomendasikan agar dapat dilanjutkan dan ditingkatkan baik volume maupun kulitas dalam pengelolaannya guna efektifitas dan efesiensi program karena setiap komunitas desa hutan $(\mathrm{KDH})$ memiliki sumber daya yang dapat dimanfaatkan oleh warga komunitasnya, lalu muncul ide-ide cara dan tujuan pemanfaatan sumber daya hutan $(\mathrm{SDH})$ tetapi harus melalui suatu proses panjang guna pembahasan dan pematangannya, dengan memperhitungkan berbagai aspek, kemudian ditetapkan sebagai sebuah pilihan cara mengatasi suatu masalah yang dihadapai masyarakat maka warga tersebut mampu memutuskan konsensus bersama dalam menentukan cara pemanfaatan SDH. Pemanfaatan SDH melalui PHBM dapat bertahan lama karena mekanismenya memperhatikan prinsip keadilan untuk semua warga sehingga menumbuhkan rasa saling percaya, hubungan saling percaya akan tumbuh ketika proses-proses sosial dalam pengelolaan hutan memberikan jaminan keadilan bagi semua pihak. Mekanisme pengorganisasiannya juga membuka partisipasi sederajat antar warga, di samping itu ada aturan yang jelas dan dipatuhi bersama tentang ganjaran dan sangsi yang harus dilaksanakan secara konsisten (Zaenuddin, 2014). Kerusakan hutan telah meningkatkan emisi karbon hampir 20\% yang sangat signifikan karena karbon dioksida merupakan salah satu gas rumah kaca yang berimplikasi pada kecenderungan pemanasan global. Kondisi cuaca yang ekstrim menyebabkan kekeringan, banjir dan taufan, serta distribusi organisme penyebab penyakit diprediksinya dapat terjadi. Kebakaran hutan merupakan salah satu bentuk gangguann yang makin sering terjadi. Dampak negatif yang ditimbulkan cukup besar mencakup kerusakan ekologis, menurunnya keanekaragaman hayati, merosotnya nilai ekonomi hutan dan produktivitas tanah, perubahan iklim mikri maupun global, dan asapnya mengganggu kesehatan masyarakat serta transportasi baik darat, sungai, danau, laut, dan udara. Berbagai upaya pencegahan dan perlindungan kebakaran hutan namun belum memberikan hasil yang optimal. Penyebab terjadinya kebakaran hutan kemungkinan terjadi secara alamiah tetapi aktivitas manusia juga menjadi salah satunya dan hanya sebagian kecil yang disebabkan oleh kejadian alam (Rasyid, 2014).

Beberapa usaha, cara, dan metode pelestarian hutan misalnya dapat dilakukan dengan mencegah perladangan berpindah yang tidak menggunakan kaidah pelestarian hutan, waspada dan hati-hati terhadap api dan reboisasi lahan gundul serta tebang pilih tanam kemballi. Cara yang pertama yaitu mencegah cara ladang berpindah atau perladangan berpindah-pindah. Terkadang petani tidak mau pusing mengenai 
kesuburan tanah. Mereka akan mencari lahan pertanian baru ketika tanah yang ditanami sudah tidak subur lagi tanpa adanya tanggung jawab membiarkan ladang tersebut terbengkalai dan tandus, sebaiknya lahan pertanian dibuat menetap dengan menggunakan pupuk untuk menyuburkan tanah yang sudah tidak produktif lagi. Cara yang kedua, menghindari pembakaran sampah, membuang punting rokok, membuat api unggun, membakar semak, membuang obor, dan lain sebagainya yang menyebabkan kebakaran hutan. Jika menyalakan api di dekat atau di dalam hutan harus diawasi dan dipantau agar tidak terjadi hal-hal yang lebih buruk. Karena kebakaran hutan dapat mengganggu kesehatan manusia dan hewan di sekitar lokasi kebakaran dan juga tempat yang jauh sekalipun jika asap terbawa angin kencang. Metode selanjutnya yatu reboisasi lahan gundul dan metode tebang pilih. Para perusahaan penebang pohon harus memilihmilih pohon mana yang sudah cukup umur dan ukuran untuk ditebang. Setelah menebang satu pohon sebaiknya diikuti dengan penanaman kembali beberapa bibit pohon untuk menggantikan pohon yang ditebang tersebut.

Lahan yang gundul dan rusak juga diusahakan dilakukan reboisasi untuk mengembalikan pepohonan dan tanaman yang telah hilang, Selanjutnya menempatkan penjaga hutan/polisi kehutanan. Dengan menempatkan satuan pengaman hutan yang jujur dan menggunakan teknologi dan persenjataan lengkap diharapkan mampu menekan maraknya aksi perusakan hutan oleh oknumoknum yang tidak bertanggung jawab. Bagi para pelaku kejahatan diberikan sangsi yang tegas dan hukuman yang berat karena hutan adalah harta suatu bangsa yang sangat berharga dan harus dipertahankan keberadaannya lalu terakhir dengan membuat arboterum yaitu merupakan salah satu bentuk konkret bagaimana merajut persaudaraan yang intim dengan alam ( $F$, 2011).

Salah satu elemen penting dalam pengelolaan hutan yaitu konsep pelestarian. Pada umumnya konsep pelestarian hutan mempunyai hubungan lingkup yang lebih luas dari segi ekologi dan sosial ekonomi suatu wilayah. Tebangan tahunan atau tebangan periodik pada hakikatnya harus sama dengan riap untuk jangka waktu yang bersangkutan.

Dengan demikian hasil kayu yang maksimal dapat diperluas sepanjang waktu tanpa membahayakan hasil di masa yang akan datang, dan kelestarian hutan pun dapat dipertahankan. Program pendidikan kepada masyarakat dan bantuan dana juga dibutuhkan dalam mengembangkan upaya konservasi. Salah satu hal yang juga penting berkaitan dengan upaya keberhasilan pelestarian hutan adalah pentingnya perhatian terhadap pengelolaan ekosistem. Pengelolaan ekosistem memadukan pengetahuan ilmiah yang mengenai berbagai hubungan ekologi, praktik pengelolaan sumber daya alam yang selama ini menekankan produksi maksimum baik berupa barang, maupun jasa perlu diperkaya dengan sudut pandang yang lebih tepat dan meluas sehingga mencakup pelestarian hutan. (Rukandar, 1995).

\section{Meningkatkan Sikap Cinta Lingkungan Bagi Siswa MI/SD Melalui Pembelajaran Menjaga Kelestarian Hutan}

Kurangnya pemahaman karakter peduli lingkungan membuat manusia memenuhi kebutuhan dengan menjadikan alam sekitar sebagai alat pemuas dan sikapnya yang kurang peduli pada lingkungan. Sebenarnya alam sekitar yang sebagai tempat berlangsungnya kehidupan membutuhkan peran manusia untuk tumbuh secara 
berkelanjutan, karena alam dan lingkungan sangat bermanfaat untuk kepentingan hidup manusia (Masruroh, 2018) Bentuk upaya untuk dapat melestarikan hutan dan lingkungan yaitu menanamkan pendidikan karakter cinta lingkungan kepada semua manusia yang harus menyentuh pada anak usia dini sebagai generasi mendatang. Pendidikan sekolah dasar (SD) strategis untuk ditanamkan pendidikan karakter. Jika karakter anak telah terbentuk sejak kecil mulai dari lingkungan sosisal sampai sekolah dasar, maka generasi masyarakat Indonesia akan menjadi manusia yang berkarakter, yang dapat menjadi penerus bangsa dan menjaga kelestarian lingkungan alam serta dapat merubah kerusakan alam yang sudah terjadi (Jacobus, 2015).

Guru memiliki peran sentral untuk membentuk dan menanamkan karakter cinta lingkungan kepada anak-anak. Oleh karena itu, sejak dini anak-anak perlu disadarkan bahwa setiap manusia memiliki tanggung jawab untuk melestarikan lingkungan hidup. Pendidikan karakter adalah sebuah sistem yang menanamkan nilai karakter pada peserta didik dan mengandung komponen pengetahuan, kesadaran individu, tekad, serta adanya kemauan dan tindakan untuk melaksanakan nilai-nilai, baik terhadap Allah SWT, diri sendiri, sesama manusia, lingkungan, maupun bangsa. Implementasi pendidikan karakter dimulai dari hal terkecil yaitu mengajarlan peserta didik untuk membuang sampah ke dalam tempat pemilahan sampah organic dan anorganik yang telah disediakan di depan kelas, kemudian merawat tanaman dengan cara siswa membawa air yang dimasukkan ke dalam botol untuk menyiram tanaman yang ada di depan kelas setiap harinya (Milutasari, 2019). Pada proses belajar mengajar dengan menerapkan pembelajaran aktif dan menanamkan karakter peduli lingkungan pada kegiatan belajar mengajar di setiap pokok bahasan maupun di luar kelas pada semua mata pelajaran. Dengan demikian, kegiatan pembelajaran selain untuk menjadikan peserta didik menguasai materi juga dapat menjadikan peserta didik mengenal, menyadari/peduli, dan menginternalisasikan nilai-nilai karakter dan menjadikannya perilaku dalam kehidupannya sehari-hari. Peduli lingkungan yang merupakan sikap dan tindakan yang berupaya mencegah kerusakan pada lingkungan alam dan sekitarnya serta mengembangkan upaya-upaya untuk memperbaiki kerusakan alam yang sudah terjadi. Selain itu kepala sekolah, guru, juga karyawan selaku warga sekolah berperan dalam memahami dan memberi contoh perilaku-perilku yang menunjukkan nilai peduli lingkungan kepada peserta didik. Karena, siswa cenderung meniru apa yang dilakukan oleh orang-orang dewasa yang di sekitarnya.

Integrasi penanaman karakter peduli lingkungan dapat berupa praktik maupun teori. Dalam hal teori siswa dibekali materi dan diberi tugas yang berkaitan dengan lingkungan. dalam hal praktek siswa diberi kegiatan akan cinta dna peduli pada lingkungan, meskipun hanya sekedar kebersihan kelas. Sebelum memulai pembelajaran guru mengevaluasi keberhasihan kelas dan pada saat pembelajaran siswa selalu dikaitkan serta diingatkan untuk peduli lingkungan (Rukandar, 1995).

Pada pelaksanaan pembelajaran guru dapat memberikan program-program yang berhubungan dengan karakter cinta lingkungan yang melibatkan siswa secara langsung dalam Program tersebut. Salah satunya pelaksnaan program dilaksanakan melalui kegiatan penghijauan secara masal yang melibatkan seluruh siswa untuk menanam dalam pot yang dapat terbuat dari botol bekas dengan ini siswa dapat 
berpartisipasi secara langsung dan mempraktekan bagaimana cara menjaga lingkungan sekitar dengan cara-cara yang sederhana. Selain itu siswa juga akan diberikan evaluasi dengan media lucu dan sederhana mengenai dampak-dampak yang ditimbulkan jika lingkungan tidak dijaga dengan baik (Paramita \& Dkk, 2017).

Dengan penerapan program Green and Clean dapat berperan penting dalam memberikan pendidikan karakter peduli lingkungan pada siswa. Karena dalam Program ini siswa diajarkan untuk mencintai lingkungannya dan pada dasarnya program Green and Clean adalah pengenalan kepada siswa bagaimana untuk mencintai dan menjaga lingkungannya melalui hal-hal yang sederhana, dengan kegiatan olah sampah yang berupa pengumpulan, pengangkutan, dan proses daur ulang. Kegiatan piket pagi, kegiatan cuci tangan yang baik dan benar, kegiatan kerapian diri, dan kegiatan perawatan taman dan lingkungan sekolah. Melalui Program ini dapat menciptakan lingkungan sekolah menjadi hijau untuk menunjang kesehatan fisik mental dan kecerdasan otak siswa. Selain itu, dapat membantu upaya pelestarian lingkungan sekolah, menarik perhatian siswa dalam kepedulian lingkungan sekolah, meningkatkan kepekaan dan motivasi siswa akan pentignya berpartisipasi dalam kebersihan sekolah. Pembelajaran dalam meningkatkan dan menjaga kelestarian hutan serta lingkungannya pada siswa $\mathrm{MI} / \mathrm{SD}$ yaitu ketika selama pembelajaran berlangsung dapat digunakan metode bercerita, bernyanyi, demonstrasi, dan bermain. Bercerita digunakan ketika menjelaskan bahaya serta dampak dari kerusakan hutan dan dampak dari pencemaran lingkungan, bernyanyi dilakukan untuk menguatkan ingatan anak tentang materi yang dipelajari. Demonstrasi dilakukan untuk menjelaskan cara apa saja yang dapat digunakan untuk menjaga kelestarian lingkungan misalnya dengan membuat kerajinan sampah, dengan ini anak dapat ikut mempraktekkan langsung. Bermain dengan permainan tebak gambar apa saja yang termasuk lingkungan yang bersih dan sehat lalu memberikan beberapa pertanyaan yang langsung dijawab oleh kelompok secara bersamaan sehingga tidak membosankan dalam pembelajaran karena merupakan metode yang menarik bagi anak.

Dengan mendidik anak dari usia dini dalam pendidikan lingkungan dapat membentuk karakter peduli lingkungan sehingga nanti akan membentuk masyarakat yang cerdas akan pengelolaan lingkungan dan dapat mengurangi kerukasan hutan dalam upaya melestarikan hutan. Dengan mengelola lingkungan yang baik maka lingkungan pun akan memberikan timbal balik yang baik, baik suasana alam yang natural maupun barang-barang yang dapat didaur ulang untuk dibuat kerajinan yang bernilai ekonomis (Masruroh, 2018).

Pendidikan lingkungan hidup dapat diintegrasikan melalui bidang studi di sekolah, pendidikan lingkungan hidup dapat dilaksanakan dengan pendekatan interdisipliner, multidisipliner dan transdisipliner di sekolah. Melalui pembelajaran IPS di sekolah dasar cukup tepat dalam mengajarkan pendidikan lingkungan hidup kepada siswa. permasalahan global dalam pembelajaran IPS adalah isu-isu lingkungan terutama berkaitan dengan akibat eksploitasi sumber daya manusia dan pengelolaan kekayaan bumi, seperti permasalahan sampah, banjir, polusi udara, dan pemanasan global. untuk mengintegrasikan pendidikan lingkungan hidup sesuai dengan tujuan pembelajaran IPS siswa mampu berpikir kritis, memecahkan permasalahan sosial dan peduli akan lingkungan. Sikap sadar akan permasalahan global terutama pada 
permasalahan lingkungan seperti lubang lapisan ozon, pemanasan global, dan banjir. Dengan pendidikan global dapat mengajak siswa berpikir global dan bertindak lokal. Peranan pembelajaran IPS di harapkan mampu menanamkan sikap sadar akan lingkungan terhadap generasi muda sebagai pewaris penghuni bumi di masa yang akan datang (Afandi, 2013). Hasil belajar IPS yang demikian tentunya mampu menjembatani pemahaman peserta didik terhadap hubungan manusia dan lingkungan alam. Pendidikan lingkungan dibuat untuk merangkul seluruh pelajaran dengan menumbuhkan sikap sadar lingkungan bagi peserta didik. Pendidikan lingkungan yang baik harus memastikan pemahaman peserta didik mengenai lingkungan tidak sebatas pengetahuan dasar semata. Arti penting dari pendidikan lingkungan adalah bentuk kepekaan terhadap problematika lingkungan dan usaha untuk mengurangi kerusakan bahkan meningkatkan kualitas keseimbangan alam melalui pendidikan (Mutiani, 2017).

\section{PENUTUP}

Indonesia sebagai Negara berkembang tidak luput dengan adanya permasalahan. Rendahnya karakter peduli lingkungan yang dimiliki oleh masyarakat akan memberi pelajaran terhadap manusia di dalamnya dengan berbagai bencana alam. Permasalahan lingkungan di Indonesia adalah kerusakan hutan yang disebabkan sebagian besar oleh aktivitas manusia. Masalah lingkungan merupakan tanggung jawab bersama yang harus ditanggung guna tercapainya lingkungan yang nyaman dan bersih. Masalah-masalah seperti kerusakan lingkungan hidup tidak akan terjadi jika setiap manusia memiliki rasa tanggung jawab dan rasa kepedulian yang tinggi. Hal penting dalam pengelolaan hutan adalah konsep pelestarian yang merupakan upaya melindungi hutan dari kerusakan hutan, kawasan hutan, dan hasil hutan yang disebabkan perbuatan manusia, kebakaran, daya-daya alam, hama, dll. Sebenarnya pengelolaan hutan membutuhkan peran manusia untuk tumbuh secara berkelanjutan, karena alam dan lingkungan sangat bermanfaat untuk kepentingan hidup manusia.

Upaya melestarikan hutan dan lingkungan dimulai dengan menanamkan pendidikan lingkungan hidup khususnya pada anak usia dini. Mendidik anak dari usia dini dalam pendidikan lingkungan diharapkan dapat membentuk karakter peduli lingkungan sehingga akan membentuk masyarakat yang cerdas akan pengelolaan lingkungan. dengan mengelola lingkungan yang baik maka akan bertimbal balik yang baik pula bagi masyarakat. Dengan kondisi hutan dan lingkungan yang sedemikian turunnya maka usaha-usaha dalam pengelolaan hutan dengan menjaga kelestariannya adalah menyelamatkan kehidupan dunia dan manusia pada umumnya.

\section{UCAPAN TERIMA KASIH}

Syukur Alhamdulillah kami panjatkan kepada Allah SWT karena berkah, rahmat, dan hidayah-Nya sehingga penulis dapat menyelesaikan artikel ini. Terimakasih kami ucapkan kepada dosen pembimbing yang selalu memberikan arahan dan motivasi sehingga artikel ini dapat terselesaikan dengan baik 


\section{REFERENSI}

Arsi, K. (2012). Rekalkulasi Penutupan Lahan Indonesia Tahun 2018. Journal of Chemical Information and Modeling, 53(9), 1689-1699. https://doi.org/10.1017/CBO9781107415 324.004

Adinugraha, H. A. (2008). Tugas mulia menyelamatkan hutan indonesia. 6(2), 18.

Afandi, R. (2013). Integrasi Pendidikan Lingkungan Hidup Melalui Pembelajaran IPS di Sekolah Dasar Sebagai Alternatif Menciptakan Sekolah Hijau. PEDAGOGIA: Jurnal Pendidikan, 2(1), 98. https://doi.org/10.21070/pedagogia.v2i1.5 0

Barri, M. F., Setiawan, A. A., Oktaviani, A. R., Prayoga, A. P., \& Ichsan, A. C. (2018). 1 Deforestasi Tanpa Henti. 2018. 1-62.

F, P. (2011). Pelestarian Hutan dalam . Hubungannya Dengan Lingkungan dan Potensi Ekonomi. In Proceeding PESAT (Psikologi, Ekonomi, Sastra, Arsitektur \&Sipil).

Jacobus, A. (2015). Program Sekolah Harmoni Hijau.

KLHK. (2018). Status Hutan dan Kehutanan Indonesia 2018. In Kementerian Lingkungan Hidup dan Kehutanan RI.

Masruroh, M. (2018). Membentuk Karakter Peduli Lingkungan Dengan Pendidikan. Jurnal Geografi Gea, 18(2), 130. https://doi.org/10.17509/gea.v18i2.13461

Milutasari, M. C. (2019). Pembinaan Karakter Peduli Lingkungan Melalui Program Adiwiyata Di Sd Negeri 16 Purwodadi.

Mutiani, M. (2017). Ips Dan Pendidikan Lingkungan: Urgensi Pengembangan Sikap Kesadaran Lingkungan Peserta Didik. SOSIO-DIDAKTIKA: Social Science Education Journal, 4(1), 45-53. https://doi.org/10.15408/sd.v4i1.5718

Paramita, V. S., \& Dkk. (2017). Manajemen Sekolah Hijau Berwawasan Lingkungan. Dharma Bhakti Ekuitas, 02(01, september), 162.
Rasyid, F. (2014). Permasalahan dan Dampak Kebakaran Hutan. 4, 47-59.

Rukandar, D. (1995). KEBIJAKAN PELESTARIAN SUMBER DAYA HUTAN DALAM RANGKA PEMBANGUNAN BERKELANUUTAN.

Supriyadi, S. (2017). Community of Practitioners: Solusi Alternatif Berbagi Pengetahuan antar Pustakawan. Lentera Pustaka: Jurnal Kajian IImu Perpustakaan, Informasi Dan Kearsipan, 2(2), 83. https://doi.org/10.14710/lenpust.v2i2.1 3476

Zaenuddin, D. et. a. (2014). Konsep Pengelolaan Hutan Berbasis Masyarakat (Phbm). http://blogdirgalaremba.blogspot.co.id/ 2014/03/konsep-pengelolaan-hutanberbasis.html 